\title{
Groundwater potency for domestic demand in Banguntapan District, Bantul Regency
}

\author{
Sekar Dinul Salamah ${ }^{1}$, Ignasius Loyola Setyawan Purnama ${ }^{1, *}$, and Vincentia Anindha Primacintya ${ }^{2}$ \\ ${ }^{1}$ Faculty of Geography, Universitas Gadjah Mada, Yogyakarta, Indonesia \\ ${ }^{2}$ Accounting Programme, Master of Science and Doctoral, Faculty of Economics and Business, Universitas Gadjah Mada, Indonesia
}

\begin{abstract}
Banguntapan District in Bantul Regency is one of the districts bordering the City of Yogyakarta. Because of its strategic location, the development of this district is very rapidly marked by population and settlement growth. As a result, the demand for facilities and infrastructure has also increased including the need for groundwater for domestic water sources. The purpose of this study is to determine the groundwater potency and domestic needs of the population. The study of domestic water demand is carried out to find out the current water needs and the level of criticality. For this reason a static groundwater potential calculation and the water needs are carried out. Calculation and analysis results show that groundwater potency in unconfined aquifers in the study area is $279,004,000 \mathrm{~m}^{3} /$ year, with safe yield of groundwater extraction are $13,109,292 \mathrm{~m}^{3} /$ year. Although groundwater extraction for domestic demand which amounted to $6,392,874 \mathrm{~m}^{3} /$ year is still smaller than the safe yield, according to the calculation of the criticality index the water is almost classified in the critically approaching criteria.
\end{abstract}

\section{Introduction}

Water is one of the most important natural resources in supporting human life, so it needs to be managed well [1-3]. Instead of other types of water (rainwater and river water), groundwater has better quality, so that it is still the main source to meet daily water needs. Therefore a study related to groundwater availability is important to know considering that groundwater is the most clean water source widely used by the community $[4,5]$. Even so the presence of groundwater is also very dependent on the geological condition of an area [6]. Therefore groundwater management starts by paying attention to the recharge area. Rainwater that falls in the area will experience infiltration. This pervasive downward movement of water will only stop if there is an impermeable layer that blocks it [7].

According to [8], groundwater potential refers to the availability and quality of groundwater. The increase in population will lead to an increase in the need for clean water. On the other hand developments and developments that occur in various sectors in an area will also affect the existence of groundwater.

Banguntapan District is located in Bantul Regency. Its location on the outskirts of the city causes the development that occurs in this district is quite rapid. In addition, according to the Bantul Regency Spatial Plan for 2010-2030, the Banguntapan District is a plan for urban settlement areas. This can be an attraction for the community to have a place to live in the District of Banguntapan.
Even now, Banguntapan District has a rapid regional development in line with population growth and settlement development. The location of the district is directly adjacent to the Sleman Regency and the City of Yogyakarta and because of the ease of access, making this district the community's choice of residence.

Regarding the land use, the residential land use in Banguntapan District has indeed been spread evenly. Although the use of irrigated paddy fields is also still quite a lot, but it does not deny the existence of land use change. This will certainly affect the use of ground water in the district. In addition to the use of water, the amount of waste disposal will also increase and affect the condition of groundwater.

Banguntapan District is included in the Merapi III Aquifer Unit which is a groundwater basin with sufficiently good groundwater conditions which generally have a depth of $0.5 \mathrm{~m}$ to $3.5 \mathrm{~m}$ and water fluctuations between $0.4 \mathrm{~m}$ to $4.6 \mathrm{~m}$ [9]. Even though the condition is still good, the use of ground water must still be monitored and accompanied by good sanitation so as not to cause various problems [10]. Therefore, this study aims to determine the magnitude of groundwater potential and domestic needs of the population. The study of domestic water needs is carried out to find out the current water needs and the level of criticality, so this research can be used as a reference so that groundwater utilization can always be sustainable.

\footnotetext{
*Corresponding author: Setyapurna@geo.ugm.ac.id
} 


\section{Method of research}

\subsection{Groundwater Potency}

Important parameters in this study are the groundwater level and groundwater level fluctuations. In this study, groundwater depth data is obtained through measurement of well water surface depth, while groundwater level fluctuations data are based on groundwater depth measurement data and interviews with well owners. Determination of the location of measurement of wells is done purposively by observing the distribution.

Groundwater potency is calculated based on static groundwater flow assumptions. The equation used is [11]:

$$
\text { Vat }=\mathrm{D} \times \mathrm{A} \times \mathrm{Sy}
$$

where Vat is the volume of groundwater that can be pumped from the aquifer, D is the thickness of the aquifer, $\mathrm{A}$ is the area and Sy is the specific yield or percentage of water that can be released from the aquifer.

To ensure the sustainability of its availability, it is necessary to know the amount of safe groundwater extraction. The calculation equation is wrong:

$$
\mathrm{HA}=\mathrm{F} . \mathrm{A} \cdot \mathrm{Sy}
$$

where HA is the safe yield and F is groundwater level fluctuation.

\subsection{Water demand}

In this study, the calculated water demand is the need for water for domestic needs which is determined according to the size of the population and the number of water needs per capita per day. According to Mangku Sitepoe [12], water demand in large cities are generally $>150$ liters/capita/day, in cities that are 80 to 150 liters/capita/day, sub-district cities 60 to 80 liters/capita/day and villages range from 30 to 60 liters/capita/day. Based on this criterion, because the Banguntapan District is in the peri-urban area, the water demand is determined to be 120 liters/person/day.

\section{Result and discussion}

\subsection{Location, area and boundary}

Banguntapan District is one of the sub-districts in Bantul Regency which is located in the northeastern part. The area of Banguntapan District is $28.48 \mathrm{~km}^{2}$, which is divided into 8 villages namely Tamanan, Wirokerten, Jambidan, Singosaren, Jagalan, Potorono, Baturetno and Banguntapan (Figure 1). Judging from the boundaries of the region, the north is bounded by Sleman Regency, the east is bounded by Piyungan District, the south is bounded by Pleret District and the west is bounded by Sewon District and Yogyakarta City.

\subsection{Climate}

The climate situation in Banguntapan District cannot be separated from the overall climate condition of Java Island, which is influenced by monsoons, namely global winds that blow due to the influence of the location of the sun, so that they will always change direction every half year. During the months of October to April when the sun is located in the southern hemisphere, Australia's mainland is a low pressure center region so that the wind blows from mainland Asia which is a center of high pressure. When through the equator this wind is diverted from the northeast (North-Easterly) to the northwest (North-Westerly). When passing through the island of Java, this wet monsoon becomes a west wind so it is often called the Wet-West Monsoon. During this period, the island of Java in general and the Kebumen Coast in particular experienced the rainy season.

In contrast, from May to October, mainland Asia became the center of low pressure and Australia became the center of high pressure. A monsoon blows from Australia and does not carry water vapor (East-dry monsoon), so that some parts of Java experience a dry season.

Based on the division of climate types from Koppen, the climate type in the District of Banguntapan is Am. In type Am, the amount of rainfall that falls in the wet month can compensate for the short dry season. So even though the Am climate has one or two dry months, the rainfall in other months is quite high, so that the vegetation is not so affected by the short dry period.

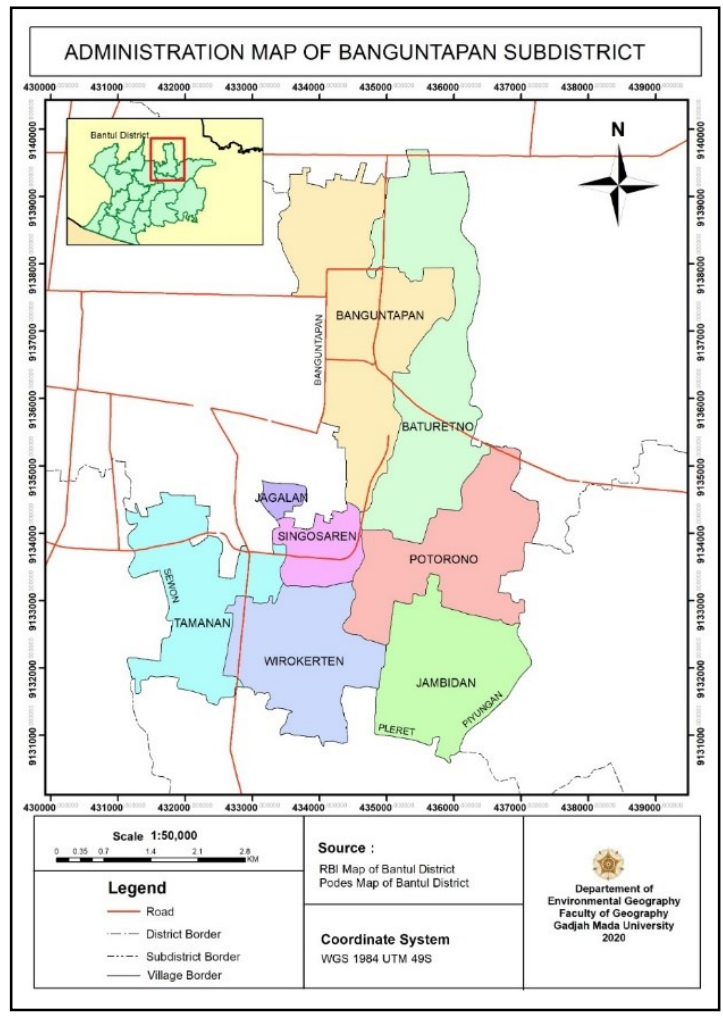

Fig. 1. Administratition map of Banguntapan 


\subsection{Geology and hydrogeology}

Geologically, Banguntapan District is located in the Young Merapi Volcanic deposit. These sediments are composed of tuff, ash, breccias, agglomerates and lava are inseparable. The Young Merapi sediment is the main compiler of the aquifer in this area.

Hydrogeologically, the Banguntapan District is included in the Merapi Volcanic Plain Aquifer Unit or often called the lower Merapi Volcanic Aquifer Unit. Most of the material making up this aquifer is sand and clay as inserts. This aquifer is classified as a major aquifer which is an aquifer that is able to supply water for domestic and industrial purposes. This aquifer groundwater supplement comes from groundwater flow from the Merapi Middle Aquifer unit and local infiltration. Judging from the characteristics of the aquifer, the permeability of this aquifer is also classified as a rapid criterion.

\subsection{Population}

Based on the recording of 2018 (Banguntapan in Number, 2019), the total population in the Banguntapan District is 145956 inhabitants with a male population of 73058 and a female population of 72898 . With an area of $28.48 \mathrm{~km}^{2}$, the population density is 5,124 people $/ \mathrm{km}^{2}$.

\subsection{Depth and fluctuation of groundwater}

Based on the results of measurements in the field, it is known that the depth of the groundwater surface not depressed in the study area ranged from 1.13 meters to 6.40 meters from the ground surface (Table 1). The shallow groundwater faces are in Tamanan Village, while the deepest groundwater level are in Banguntapan Village. In general the average depth of groundwater level in Banguntapan District is $3.49 \mathrm{~m}$.

Table 1. Depth and fluctuations of groundwater

\begin{tabular}{|l|c|c|}
\hline \multicolumn{1}{|c|}{ Locations } & Depth, $\mathrm{m}$ & Fluctuation, $\mathrm{m}$ \\
\hline Banjar, Tamanan & 1,13 & 1,00 \\
\hline Glondong, Wirokerten & 3,10 & 1,50 \\
\hline Jambidan, Jambidan & 1,97 & 1,00 \\
\hline Kretek Lor, Jambidan & 2,75 & 1,50 \\
\hline Singosaren I, Singosaren & 3,50 & 1,50 \\
\hline Sayangan, Jagalan & 3,95 & 1,50 \\
\hline Potorono, Potorono & 4,00 & 1,50 \\
\hline Plakaran, Baturetno & 2,00 & 1,00 \\
\hline Pelem, Baturetno & 3,10 & 2,00 \\
\hline Maguwo, Banguntapan & 6,40 & 2,00 \\
\hline Wonocatur, Banguntapan & 5,05 & 2,50 \\
\hline Plumbon, Banguntapan & 4,90 & 2,50 \\
\hline Average & 3,49 & 1,63 \\
\hline
\end{tabular}

Judging from the depth of the groundwater level it can be said that the depth of the groundwater level in the Banguntapan District is included in the shallow criteria, because most of the area has a groundwater depth of less than $5 \mathrm{~m}$. There is only one well whose depth exceeds 5 $\mathrm{m}$, namely in Maguwo Hamlet with a groundwater level depth of $6.40 \mathrm{~m}$. Noting this situation, it can be said that in terms of groundwater depth, groundwater potential in Banguntapan District is relatively high.

Besides groundwater level, groundwater level fluctuation is also an important aspect in reviewing groundwater potential in an area. Groundwater fluctuations referred to here are groundwater level fluctuations caused by seasonal differences, namely the rainy season and the dry season, the data of which are obtained from measurement results during research and the results of interviews with well owners. Areas with low groundwater fluctuations are said to have groundwater potential good. To find out groundwater level fluctuations, this is done through groundwater level observations and interviews with well owners. Noting groundwater fluctuations, it is known that in general groundwater fluctuations in Banguntapan District are classified as low $(<2 \mathrm{~m})$, ranging from 1.00 meters to $2.50 \mathrm{~m}$ (only 2 wells).

If we look at the spatial distribution, we can see that there is a tendency that the depth of the groundwater level is getting deeper north. For groundwater fluctuations, although there is a tendency in the north is greater, in general it is more variable.

\subsection{Groundwater potency}

According to [13], groundwater potential can be determined qualitatively through overlaying and analyzing aspects of aquifer conditions, groundwater level and fluctuations and groundwater quality. However, for this study groundwater potential was obtained based on groundwater potential calculations in each village, namely the multiplication between aquifer thickness (D), specific yield (Sy), and the area of each village (A), while groundwater safe yield were the results of multiplication between groundwater fluctuation (F), village area (A) and specific yield (Sy) [14].

Determination of the thickness of the aquifer is done by paying attention to rock layers in 2 bore wells located in the study area, namely the Jomblangan and Wonocatur Drilling Wells. Specific yield is determined based on the type of aquifer rock in the wellbore which is then converted using a specific yield table according to Johnson [15]. Calculation results are shown in Tables 2 and 3.

Table 2. Groundwater potency in Banguntapan

\begin{tabular}{|l|r|r|r|r|}
\hline \multicolumn{1}{|c|}{ Village } & $\mathrm{D}, \mathrm{m}$ & \multicolumn{1}{c|}{$\mathrm{A}, \mathrm{m}^{2}$} & \multicolumn{1}{c|}{ Sy } & Vat, $\mathrm{m}^{3} /$ year \\
\hline Banguntapan & 35 & 8.330 .000 & 0,28 & 81.634 .000 \\
\hline Baturetno & 35 & 3.940 .000 & 0,28 & 38.512 .000 \\
\hline Singosaren & 35 & 670.000 & 0,28 & 6.566 .000 \\
\hline Jagalan & 35 & 270.000 & 0,28 & 2.646 .000 \\
\hline Tamanan & 35 & 3.750 .000 & 0,28 & 36.750 .000 \\
\hline Wirokerten & 35 & 3.860 .000 & 0,28 & 37.828 .000 \\
\hline Potorono & 35 & 3.900 .000 & 0,28 & 38.220 .000 \\
\hline Jambidan & 35 & 3.760 .000 & 0,28 & 36.848 .000 \\
\hline \multicolumn{5}{|c|}{ Groundwater Potency } \\
\hline
\end{tabular}


Table 3. Safe yield of groundwater use in Banguntapan

\begin{tabular}{|c|c|c|c|c|}
\hline Village & $\mathrm{F}, \mathrm{m}$ & $\mathrm{A}, \mathrm{m}^{2}$ & Sy & $\mathrm{HA}, \mathrm{m}^{3} /$ year \\
\hline Banguntapan & 2,33 & 8.330 .000 & 0,28 & 5.434 .492 \\
\hline Baturetno & 1,50 & 3.940 .000 & 0,28 & 1.654 .800 \\
\hline Singosaren & 1,50 & 670.000 & 0,28 & 281.400 \\
\hline Jagalan & 1,50 & 270.000 & 0,28 & 113.400 \\
\hline Tamanan & 1,00 & 3.750 .000 & 0,28 & 1.050 .000 \\
\hline Wirokerten & 1,50 & 3.860 .000 & 0,28 & 1.621 .200 \\
\hline Potorono & 1,50 & 3.900 .000 & 0,28 & 1.638 .000 \\
\hline Jambidan & 1,25 & 3.760 .000 & 0,28 & 1.316 .000 \\
\hline \multicolumn{4}{|c|}{ Safe yield of groundwater usage } & 13.109 .292 \\
\hline
\end{tabular}

Looking at the results of the calculations in Table 2, it is known that the groundwater potency in the Banguntapan District is $279,004,000 \mathrm{~m}^{3} /$ year, with the safe yield of extracting groundwater $13,109,292 \mathrm{~m}^{3} /$ year (Table 3). The results of the calculation of water needs for domestic purposes show a value of 6,392,874 $\mathrm{m}^{3} /$ year, so that it is still statistically below the safe yield (Table 4).

Table 4. Water demand for domestic usage

\begin{tabular}{|l|r|r|}
\hline \multicolumn{1}{|c|}{ Village } & \multicolumn{1}{|c|}{$\begin{array}{c}\text { Population } \\
\text { (person) }\end{array}$} & $\begin{array}{c}\text { Water Demand } \\
\left(\mathrm{m}^{3} / \text { year }\right)\end{array}$ \\
\hline Banguntapan & 58.977 & 2.583 .193 \\
\hline Baturetno & 20.147 & 882.439 \\
\hline Singosaren & 5.277 & 231.133 \\
\hline Jagalan & 3.978 & 174.236 \\
\hline Tamanan & 15.756 & 690.113 \\
\hline Wirokerten & 16.060 & 703.428 \\
\hline Potorono & 14.964 & 655.423 \\
\hline Jambidan & 10.797 & 472.909 \\
\hline \multicolumn{2}{|c|}{ Total } & 6.392 .874 \\
\hline
\end{tabular}

However, if the water criticality index is calculated it is almost in the near critical category. The water criticality index according to [16] states that if the water criticality index between 0.50 to 0.75 is relatively close to critical. With a water demand of $6,392,874 \mathrm{~m}^{3} /$ year divided by a safe yield of $13,109,292 \mathrm{~m}^{3} /$ year, a figure of 0.49 will be obtained. If the groundwater needs are included for purposes other than domestic (for example hotels and industries) it may be critical to be in the near critical criteria.

\section{Conclusion}

Based on the results of calculations and analysis, it is known that the groundwater potential in the unconfined aquifer in the study area is $279,004,000 \mathrm{~m}^{3}$ /year, with safe groundwater extraction results of 13,109,292 $\mathrm{m}^{3} /$ year.

Although the extraction of groundwater for domestic demand which amounted to $6,392,874 \mathrm{~m}^{3} /$ year is still smaller than the safe yield, according to the calculation of the criticality index the water is almost classified in the critically approaching criteria.

This article is part of a study entitled "Groundwater Potency for Domestic Demand in Banguntapan District, Bantul Regency" financed from the 2020 Final Assignment Recognition (Rekognisi Tugas Akhir/RTA) Programme of Universitas Gadjah Mada.

\section{References}

1. A.F. Moench, P.M. Barlow, Journal of Hydrology 230:192-2010 (2000).

2. R.J. Lubis, Y. Sakura, R. Delinom, Indonesia. Hydrogeology Journal, 16:927-938 (2008).

3. A.A. Fenta, A. Kifle, Hydrogeology Journal 23,2015:195-206 (2014).

4. A.M. Hoque, M.M. Hoque, K.M. Ahmed, Hydrogeology Journal, 15:1523-1534 (2007).

5. S.A. Naghibi, H.A. Pourghasemi, Environ Monit Asses 188,44:1-25 (2015).

6. T. Kumar, A.K. Gautam, D.C. Jhariya, Environ. Earth Sci., 75,649:1-16 (2016).

7. Purnama, Jurnal Geografi 16(1):54-59 (2019). [in Bahasa Indonesia].

8. K.R. Rushton, Groundwater Hydrology: Conceptual and Computational Models. John Wiley \& Sons Ltd, The Atrium, Southern Gate, Chichester, West Sussex (2003).

9. S. Purnama, Suyono, B. Sulaswono, Forum Geografi, 21,2:111-122 (2007). [in Bahasa Indonesia].

10. V.Y. Tam, T.T.V. Nga, Journal of Environmental Management, 227:107-116(2018).

11. S. Purnama, Hidrologi Airtanah. Penerbit Kanisius, Yogyakarta, (2010). [in Bahasa Indonesia].

12. Y. Priyana D. Safriningsih, Forum Geografi 19,1:81-87(2005). [in Bahasa Indonesia].

13. M. Nagarajan, S. Singh, J. Indian Soc. Remote Sens 37:69-77(2009).

14. Purnama, Majalah Geografi Indonesia 33,1:1625(2019). [in Bahasa Indonesia].

15. D.K. Todd, L.W. Mays, Groundwater Hydrology. John Wiley \& Sons, New York (2005).

16. Notodihardjo, Pengelolaan Sumberdaya Air untuk Pengembangan Lingkungan Hidup. Buletin ASAI No.3. CV. Sanjaya, Jakarta (1982). [in Bahasa Indonesia]. 